\title{
Perbandingan Pengaruh Nifedipin 20 mg per Oral 2 Jam Preoperasi dengan Plasebo terhadap Suhu Inti pada Pasien yang Menjalani Operasi Modified Radical Mastectomy dengan Anestesi Umum
}

\author{
Saleh Trisnadi, ${ }^{1}$ Suwarman, ${ }^{2}$ Abdul Muthalib Nawawi ${ }^{2}$ \\ ${ }^{1}$ Bagian Instalasi Bedah Sentral RSUD Al-Ihsan Kabupaten Bandung, ${ }^{2}$ Departemen Anestesiologi \\ dan Terapi Intensif Fakultas Kedokteran Universitas Padjadjaran/Rumah Sakit Dr. Hasan Sadikin \\ Bandung
}

\begin{abstract}
Abstrak
Upaya pencegahan hipotermia dapat dilakukan dengan mengurangi perbedaan antara suhu inti dan perifer sebelum dilakukan pembedahan dengan pemberian vasodilator. Tujuan penelitian ini untuk mengetahui efek penggunaan antara nifedipin $20 \mathrm{mg}$ dan plasebo per oral 2 jam preoperasi selama operasi modifikasi mastektomi radikal terhadap penurunan suhu tubuh. Penelitian menggunakan metode prospektif, terkontrol, tersamar, buta ganda pada 30 pasien berusia 18-60 tahun, status fisik American Society of Anesthesiologist (ASA) I dan II, yang menjalani operasi modifikasi mastektomi radikal di Rumah Sakit Dr. Hasan Sadikin Bandung pada Juni sampai Agustus 2012. Secara acak dibagi menjadi 2 kelompok, yaitu kelompok yang mendapat nifedipin $20 \mathrm{mg}$ per oral 2 jam preoperasi dengan plasebo. Dilakukan pencatatan suhu timpani setiap 10 menit dari awal induksi hingga akhir anestesi. Data hasil penelitian diuji secara statistik dengan Uji Mann-Whitney. Suhu inti rata-rata pada kelompok nifedipin adalah $36,37^{\circ} \mathrm{C}$ lebih besar dibandingkan dengan kelompok kontrol yaitu $35,61^{\circ} \mathrm{C}$ dengan perbedaan bermakna $(\mathrm{p}<0,05)$. Simpulan penelitian ini menunjukkan bahwa penggunaan obat nifedipin dapat mencegah hipotermia selama operasi dibandingkan dengan plasebo (kontrol).
\end{abstract}

Kata kunci: Nifedipin, suhu inti tubuh, vasodilator

\section{Comparison of Core Temperature in Patients who Received 2 Hour Preoperative 20 mg Oral Nifedipine in Modified Radical Mastectomy Surgery under General Anesthesia}

\begin{abstract}
The strategy for initial redistribution hypothermia prevention is based on the reduction of the heat gradient between the core and the periphery before surgery by administering vasodilators. The purpose of this study was to assess the effect of $20 \mathrm{mg}$ oral nifedipine given 2 hours before anesthesia in preventing hypothermia in patients undergoing modified radical mastectomy under general anesthesia and to compare the decrease of body temperature between the use oral nifedipine and placebo. The study was performed using prospective method in a, randomized double-blind controlled manner in 30 patients, aged 18-60 years old and, American Society of Anesthesiologist (ASA) physical status I-II, who underwent modified radical mastectomy surgery at Dr. Hasan Sadikin General Hospital Bandung during the period of June until August 2012. Patients, were randomly divided into two groups. One group received $20 \mathrm{mg}$ oral nifedipine 2 hours before general anesthesia and the other group received placebo. Tymphanic temperatures were recorded during anesthesia in 10 minute intervals. The data were tested statistically using the Mann-Whitney test. The average core temperature in the nifedipine group was $36.37^{\circ} \mathrm{C}$ which was higher than that of the control group $35.61{ }^{\circ} \mathrm{C}(\mathrm{p}<0.05)$. It can be concluded that the use of nifedipine can prevent intraoperative hypothermia
\end{abstract}

Key words: Core temperature, nifedipine, vasodilator

Korespondensi: Saleh Trisnadi, dr.,SpAn, Bagian Instalasi Bedah Sentral RSUD Al-Ihsan Kab. Bandung,Jl. Kiastramanggala Baleendah Kab. Bandung, Telp/Faksmili 022-5940872/022-5941709, Mobile 081320725002, Email saleh95yakin@ gmail.com 


\section{Pendahuluan}

Hipotermia merupakan komplikasi yang masih sering terjadi selama tindakan pembedahan. ${ }^{1}$ Sekitar $60 \%$ pasien dalam keadaan hipotermia ketika tiba ruang pemulihan. ${ }^{2}$ Pada penelitian terhadap pasien yang menjalani operasi daerah abdomen, sebanyak $46 \%$ pasien mengalami hipotermia pada permulaan operasi dan lebih dari sepertiga terjadi pada saat tiba di ruang pemulihan. $^{2}$

Komplikasi hipotermia ini dapat dicegah, namun masih belum menjadi perhatian. Satu dari tiga pasien dapat mengalami hipotermia selama operasi apabila tidak dilakukan upaya preventif. Sebuah penelitian terhadap 8.083 kasus pembedahan di Eropa, didapatkan hanya $19,4 \%$ pasien yang mendapatkan pemantauan selama operasi. ${ }^{3}$

Beberapa penelitian membuktikan dampak negatif hipotermia, antara lain meningkatnya risiko terjadi perdarahan, iskemia miokardium, pemulihan pascaanestesi lebih lama, gangguan penyembuhan luka, serta peningkatan risiko infeksi. Hipotermia perioperatif ternyata juga terbukti meningkatkan biaya perawatan dan lamanya perawatan. ${ }^{4,5}$

Rumah Sakit Dr. Hasan Sadikin Bandung mempunyai 20 kamar operasi dengan jumlah operasi tahun 2009 ialah 15.976 operasi (data Instalasi Bedah Sentral RSHS tahun 2009). Alat penghangat yang dipakai selama pembedahan adalah dua unit warmer water mattras serta satu buah radiant warmer. Penghangat yang digunakan pascaoperasi di ruang pemulihan adalah 2 unit air forced warmer, 10 unit lampu penghangat, serta 1 (satu) buah radiant warmer (data inventaris alat anestesia RSHS). Jumlah penghangat tersebut masih tidak sebanding dengan jumlah pasien yang membutuhkannya, sehingga perlu alternatif penggunaan metode lainnya yang dapat diterapkan secara efisien, praktis, serta alat atau bahan tersebut mudah didapat.

Penurunan suhu inti tubuh terjadi dalam 1 (satu) jam pertama sebesar $0,5{ }^{\circ} \mathrm{C}$ sampai 1,5 ${ }^{0} \mathrm{C}$. Secara garis besar mekanisme penurunan suhu selama anestesia terjadi dalam beberapa proses. Pertama, kehilangan kalor pada kulit oleh karena proses radiasi, konveksi, konduksi, dan evaporasi, yang lebih lanjut menyebabkan redistribusi kalor dari inti tubuh ke perifer. Kedua, penurunan produksi kalor tubuh oleh karena terjadinya penurunan laju metabolisme tubuh. Kehilangan kalor yang terjadi melalui kulit merupakan mekanisme paling dominan selama anestesia. ${ }^{1,6,7}$

Upaya preventifhipotermia dapat ditempuh secara aktif dengan mempergunakan alat yang dapat menghantarkan kalor eksternal kepada tubuh seperti matras penghangat elektrik dan penggunaan material insulator (daya hantar panas yang buruk) pada tubuh pasien seperti selimut katun. ${ }^{8-10}$ Selain itu prewarming aktif dapat dilakukan pula dengan mempergunakan vasodilator untuk meminimalisir hipotermia.

Vasodilatasi dapat mengurangi terjadinya hipotermia dengan cara meningkatkan panas pada jaringan perifer serta panas tubuh total sehingga perbedaan suhu inti dengan perifer dapat dikurangi agar redistribusi hipotermia dapat diminimalisir. Salah satu jenis obat yang menyebabkan vasodilatasi ialah nifedipin yang merupakan obat antihipertensi yang bersifat vasodilator. ${ }^{3,5,11}$

Penelitian ini bertujuan untuk mengetahui pengaruh pemberian nifedipin $20 \mathrm{mg}$ melalui oral 2 jam preoperatif pada operasi modifield radical mastectomy dengan anestesia umum dalam mencegah kejadian hipotermia selama operasi.

\section{Subjek dan Metode}

Jenis penelitian ini merupakan eksperimental dengan menggunakan rancangan acak lengkap terkontrol buta ganda. Subjek penelitian ini adalah pasien di Rumah Sakit Dr. Hasan Sadikin (RSHS) Bandung, dengan kriteria inklusi, yaitu pasien yang menjalani operasi modified radical mastectomy memakai anestesia umum, status fisik American Society of Anesthesiologist (ASA) I dan II, usia 18-60 tahun. Kriteria eksklusi, adalah pasien dengan subfebris atau demam, obesitas, memiliki penyakit tiroid, disotonomia atau sindrom Raynaud, dan hipertensi. Pasien dikeluarkan dari penelitian ini apabila operasi 
berlangsung lebih dari 3 jam dan jika terjadi perdarahan lebih dari 20\% ekstirvasi volume darah pasien.

Setelah mendapat persetujuan dari Komite Etik Penelitian Kesehatan Fakultas Kedokteran Universitas Padjadjaran/RumahSakitDr.Hasan Sadikin (RSHS) Bandung, dan penandatangan formulir persetujuan (informed consent) oleh pasien, dilakukan randomisasi menggunakan tabel bilangan random, sampel dibagi menjadi 2 (dua) kelompok, kelompok I (nifedipin) dan kelompok II (kontrol).

Pada kelompok I, masing-masing subjek diberikan nifedipin $20 \mathrm{mg}$ per oral saat 2 (dua) jam sebelum operasi, sedangkan kelompok II diberikan plasebo sebagai kontrol. Suhu kamar operasi diatur pada suhu 24 derajat Celcius, pasien berbaring terlentang, lalu dipasang alat pemantauan pada tubuh pasien serta dicatat data awal suhu timpani, laju nadi, dan saturasi. Selanjutnya pasien dilakukan induksi dengan propofol $2 \mathrm{mg} / \mathrm{kgBB}$, fentanil $2 \mu \mathrm{g}$, atrakurium $0,5 \mathrm{mg} / \mathrm{kgBB}$, dan volatil isofluran, kemudian dilakukan intubasi.

Selama proses pembedahan berlangsung, anestesi dipertahankan dengan menggunakan oksigen dalam $\mathrm{N}_{2} \mathrm{O} 60 \%$ dan fresh gas flow $4 \mathrm{~L} /$ menit. Pernapasan dikontrol dengan volume tidal $6 \mathrm{~mL} / \mathrm{kgBB}$ dan frekuensi pernapasan 12 kali/menit. Sebelum induksi diberikan cairan infus $10 \mathrm{~mL} / \mathrm{kgBB}$ yang diambil dari tempat penghangat yang telah diatur dengan suhu 40 ${ }^{0} \mathrm{C}$. Perdarahan yang terjadi digantikan dengan memakai cairan kristaloid sebanyak 3 (tiga) kali volume perdarahan. Pemantauan standar yang dilakukan yaitu elektrokardiografi (EKG), laju nadi, pulse oximetry, dan juga dilakukan pemantauan suhu membran timpani setiap 10 menit hingga akhir anestesi. Suhu kamar dan lama anestesi juga dicatat. Pada akhir operasi, dilakukan reversal dengan neostigmin 0,04 $\mathrm{mg} / \mathrm{kgBB}$ dan atropin $0,02 \mathrm{mg} / \mathrm{kgBB}$.

\section{Hasil}

Hasil analisis statistika menunjukkan bahwa karakteristik umum kedua kelompok tidaklah berbeda signifikan $(p>0,05)$, baik dalam hal usia, tinggi badan, berat badan, indeks massa tubuh (IMT), jumlah cairan, dosis fentanil, suhu ruangan, suhu membran timpani maupun lama anestesia.

Suhu tubuh inti rata-rata kedua kelompok perlakuan menurun selama proses anestesia. Suhu awal rata-rata (sebelum induksi) pada kelompok nifedipin $20 \mathrm{mg}$ adalah $37,150{ }^{\circ} \mathrm{C}$. Pada kelompok nifedipin $20 \mathrm{mg}$ penurunan suhu terlihatmulai dari sejakinduksi dilakukan. Penurunan suhu berlangsung hingga menit ke70 serta sedikit meningkat kembali pada menit ke-80 dan 100. Selanjutnya fluktuatif dan pada menit ke-160 suhu menurun hingga menjadi $36,10{ }^{\circ} \mathrm{C}$ yang merupakan suhu terendah yang dicapai kelompok nifedipin $20 \mathrm{mg}$, sedangkan pada kelompok kontrol, penurunan suhu inti terjadi lebih tajam, yakni dari suhu awal 36,96 ${ }^{\circ} \mathrm{C}$ sebelum induksi menjadi $35,05{ }^{\circ} \mathrm{C}$ pada menit ke-170, suhu terakhir ini merupakan suhu terendah yang dicapai pada kelompok

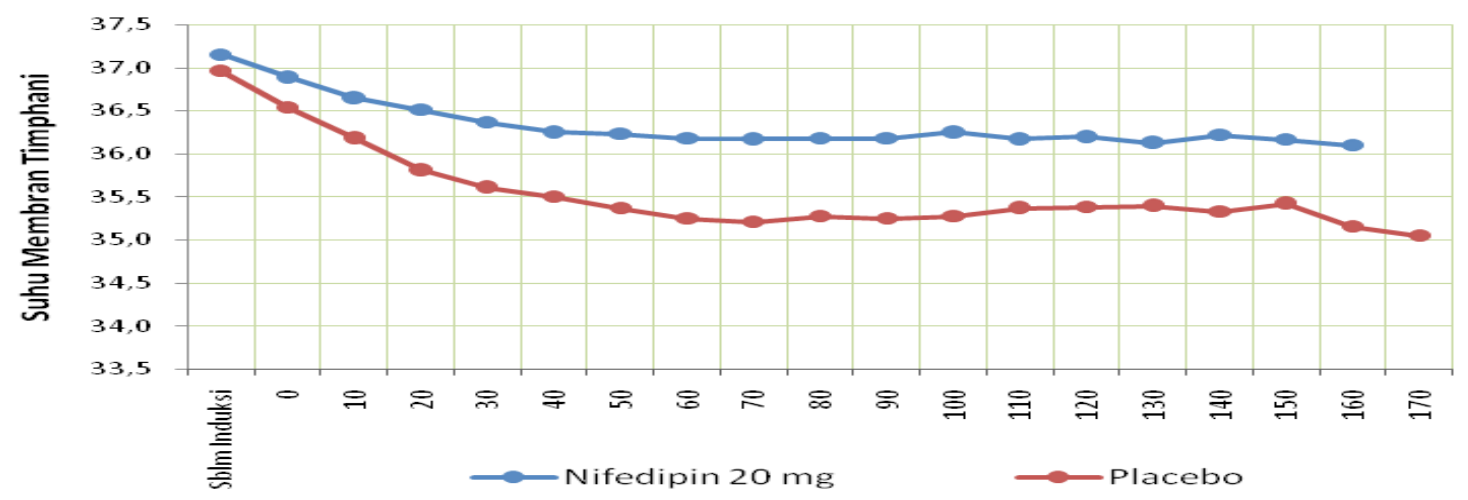

Gambar 1 Perkembangan Suhu Inti pada Kedua Kelompok Penelitian 
Tabel 1 Nilai Simpangan Baku Rata-rata dan Rentang Karakteristik

\begin{tabular}{|c|c|c|c|}
\hline \multirow{2}{*}{ Variabel } & Nifedipin $20 \mathrm{mg}$ & Kontrol & \multirow{2}{*}{ Nilai $_{l_{1}}$} \\
\hline & $(n=15)$ & $(n=15)$ & \\
\hline \multicolumn{4}{|l|}{ Usia (tahun) } \\
\hline Rata-rata (SD) & $45,2(8,8)$ & $49,1(8,7)$ & \multirow{2}{*}{0,229} \\
\hline Rentang & $33-59$ & $34-60$ & \\
\hline \multicolumn{4}{|l|}{ Tinggi badan $(\mathrm{cm})$} \\
\hline Rata-rata (SD) & $150,5(3,9)$ & $148,9(3,4)$ & \multirow{2}{*}{0,267} \\
\hline Rentang & $145-157$ & $145-155$ & \\
\hline \multicolumn{4}{|l|}{ Berat badan $(\mathrm{kg})$} \\
\hline Rata-rata (SD) & $54,4(8,7)$ & $50,1(5)$ & \multirow{2}{*}{0,110} \\
\hline Rentang & $43-68$ & $43-60$ & \\
\hline \multicolumn{4}{|c|}{ Body mass index (BMI; kg/m²) } \\
\hline Rata-rata (SD) & $23,9(3,1)$ & $22,4(2,2)$ & \multirow{2}{*}{0,144} \\
\hline Rentang & $19,1-28$ & $20-26$ & \\
\hline \multicolumn{4}{|l|}{ Jumlah cairan (mL) } \\
\hline Rata-rata (SD) & $1.683,3(231,2)$ & $1.716,7(242,5)$ & \multirow{2}{*}{0,595} \\
\hline Rentang & $1.500-2.100$ & $1.250-2.000$ & \\
\hline \multicolumn{4}{|l|}{ Dosis fentanil $(\mu \mathrm{g})$} \\
\hline Rata-rata (SD) & $105(10,4)$ & $111,7(20,8)$ & \multirow{2}{*}{0,624} \\
\hline Rentang & $100-125$ & $100-150$ & \\
\hline \multicolumn{4}{|l|}{ Suhu ruangan $\left({ }^{\circ} \mathrm{C}\right)$} \\
\hline Rata-rata (SD) & $24(0,1)$ & $24,1(0,1)$ & \multirow{2}{*}{0,285} \\
\hline Rentang & $23,9-24,2$ & $23,9-24,3$ & \\
\hline \multicolumn{4}{|l|}{ Suhu membran timpani $\left({ }^{\circ} \mathrm{C}\right)$} \\
\hline Rata-rata (SD) & $37,2(0,2)$ & $37(0,3)$ & \multirow{2}{*}{0,068} \\
\hline Rentang & $36,8-37,5$ & $36,5-37,5$ & \\
\hline \multicolumn{4}{|l|}{ Lama anestesia (menit) } \\
\hline Rata-rata (SD) & $133,3(14)$ & $136(20,3)$ & \multirow{2}{*}{0,679} \\
\hline Rentang & $110-160$ & $110-180$ & \\
\hline
\end{tabular}

Keterangan: bermakna $(\mathrm{p}<0,05)$ Nilai $\mathrm{p}$ dihitung berdasarkan uji-t, kecuali tinggi badan, jumlah cairan, dosis fentanil dan suhu ruangan dihitung berdasarkan Uji Mann-Whitney karena salah satu kelompok data tidak berdistribusi normal. SD: simpangan baku

kontrol (Gambar 1; Tabel 2).

Semua subjek pada penelitian mengalami penurunan suhu dengan derajat yang berbeda. Derajat penurunan suhu inti rata-rata pada kelompok nifedipin $20 \mathrm{mg}$ adalah sebesar 0,07 ${ }^{\circ} \mathrm{C}$, sedangkan kelompok kontrol mengalami penurunan suhu inti lebih tajam yakni sebesar $0,10^{\circ} \mathrm{C}$.

Perbandingan suhu inti antara kelompok nifedipin $20 \mathrm{mg}$ dan kelompok kontrol saat sebelum induksi anestesia terdapat perbedaan yang tidak signifikan $(p>0,05)$, tetapi sejak induksi dilaksanakan mulai terjadi perbedaan bermakna antara suhu inti pada kelompok nifedipin $20 \mathrm{mg}$ dan suhu kelompok kontrol $(p<0,05)$. Perbedaan ini terus berlangsung hingga menit ke-160 pascainduksi, suhu inti kelompok nifedipin ternyata cenderung lebih tinggi daripada kelompok kontrol. Selain itu, suhu inti pada kelompok nifedipin $20 \mathrm{mg}$ 
Tabel 2 Nilai Rata-rata dan Derajat Penurunan Suhu Inti antara Kedua Kelompok Perlakuan

\begin{tabular}{|c|c|c|c|c|c|c|c|c|}
\hline \multirow{2}{*}{$\begin{array}{c}\text { Saat } \\
\text { Pengukuran } \\
\text { Suhu }\end{array}$} & \multicolumn{2}{|c|}{ Suhu Inti $\left({ }^{\circ} \mathrm{C}\right)$} & \multirow[b]{2}{*}{$\mathbf{t}$} & \multirow[b]{2}{*}{$\mathbf{p}$} & \multicolumn{2}{|l|}{$\Delta \mathrm{T}$} & \multirow[b]{2}{*}{$\mathbf{t}$} & \multirow[b]{2}{*}{$\mathbf{p}$} \\
\hline & $\begin{array}{c}\text { Nifedipin } 20 \\
\text { mg }(n=15)\end{array}$ & $\begin{array}{c}\text { Kontrol } \\
(n=15)\end{array}$ & & & $\begin{array}{l}\text { Nifedipin } 20 \\
\text { mg }(n=15)\end{array}$ & $\begin{array}{c}\text { Kontrol } \\
(n=15)\end{array}$ & & \\
\hline $\mathrm{T}_{\text {Sblm Induksi }}$ & 37,15 & 36,96 & 1,900 & 0,068 & & & & \\
\hline $\mathrm{T}_{0}$ & 36,89 & 36,53 & 3,139 & 0,005 & $-0,26$ & $-0,43$ & 2,114 & 0,044 \\
\hline $\mathrm{T}_{10}$ & 36,65 & 36,19 & 4,017 & 0,001 & $-0,24$ & $-0,35$ & 1,521 & 0,140 \\
\hline $\mathrm{T}_{20}$ & 36,51 & 35,81 & 6,501 & 0,000 & $-0,14$ & $-0,37$ & 2,636 & 0,014 \\
\hline $\mathrm{T}_{30}$ & 36,37 & 35,61 & 6,835 & 0,000 & $-0,15$ & $-0,20$ & 1,586 & 0,125 \\
\hline $\mathrm{T}_{40}$ & 36,25 & 35,50 & 7,331 & 0,000 & $-0,11$ & $-0,11$ & 0,000 & 1,000 \\
\hline $\mathrm{T}_{50}$ & 36,23 & 35,37 & 9,614 & 0,000 & $-0,02$ & $-0,13$ & 2,283 & 0,030 \\
\hline $\mathrm{T}_{60}$ & 36,18 & 35,25 & 9,561 & 0,000 & $-0,05$ & $-0,12$ & 1,246 & 0,223 \\
\hline $\mathrm{T}_{70}$ & 36,17 & 35,21 & 9,362 & 0,000 & $-0,01$ & $-0,04$ & 0,487 & 0,632 \\
\hline $\mathrm{T}_{80}$ & 36,18 & 35,27 & 8,288 & 0,000 & 0,01 & 0,07 & $-0,936$ & 0,357 \\
\hline $\mathrm{T}_{90}$ & 36,18 & 35,25 & 9,561 & 0,000 & 0,00 & $-0,03$ & 0,389 & 0,701 \\
\hline $\mathrm{T}_{100}$ & 36,25 & 35,27 & 7,834 & 0,000 & 0,07 & 0,03 & 0,613 & 0,546 \\
\hline $\mathrm{T}_{110}$ & 36,17 & 35,37 & 5,503 & 0,000 & $-0,08$ & 0,10 & $-2,397$ & 0,023 \\
\hline $\mathrm{T}_{120}$ & 36,20 & 35,38 & 5,211 & 0,000 & 0,03 & 0,00 & 0,332 & 0,744 \\
\hline $\mathrm{T}_{130}$ & 36,13 & 35,40 & 3,649 & 0,005 & $-0,07$ & 0,02 & $-1,875$ & 0,078 \\
\hline $\mathrm{T}_{140}$ & 36,21 & 35,33 & 3,130 & 0,017 & 0,08 & $-0,07$ & $-0,138$ & 0,893 \\
\hline $\mathrm{T}_{150}$ & 36,17 & 35,43 & 3,630 & 0,027 & $-0,05$ & 0,10 & $-0,061$ & 0,955 \\
\hline $\mathrm{T}_{160}$ & 36,10 & 35,15 & - & - & $-0,07$ & $-0,27$ & - & - \\
\hline $\mathrm{T}_{170}$ & - & 35,05 & - & - & - & $-0,10$ & - & - \\
\hline $\mathrm{T}_{\text {rata-rata }}$ & 36,37 & 35,61 & 9,384 & 0,000 & $-0,07$ & $-0,10$ & 2,617 & 0,018 \\
\hline
\end{tabular}

Keterangan: $\mathrm{T}_{\text {sblmInduksi }}:$ Sebelum induksi, $\mathrm{T}_{10}: 10$ menit, $\mathrm{T}_{20}: 20$ menit, $\mathrm{T}_{30}: 30$ menit, $\mathrm{T}_{40}: 40$ menit, $\mathrm{T}_{50}: 50$ menit, $\mathrm{T}_{60}: 60$ menit, $\mathrm{T}_{70}: 70$ menit, $\mathrm{T}_{80}: 80$ menit, $\mathrm{T}_{90}: 90$ menit, $\mathrm{T}_{100}: 100$ menit, $\mathrm{T}_{110}: 110$ menit, $\mathrm{T}_{120}: 120$ menit, $\mathrm{T}_{130}: 130$ menit, $\mathrm{T}_{140}: 140$ menit, $\mathrm{T}_{150}: 150$ menit, $\mathrm{T}_{160}: 160$ menit, $\mathrm{T}_{170}: 170$ menit, $\mathrm{t}:$ Uji-t: bermakna $(\mathrm{p}<0,05)$, Nilai $\mathrm{p}$ dihitung berdasarkan uji-t.

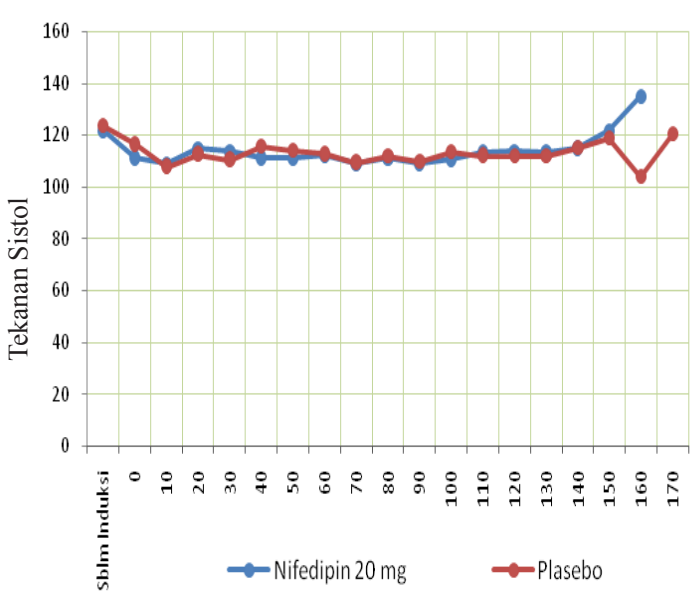

Gambar 2 Perbandingan Tekanan Sistol Rata-Rata Kelompok Nifedipin 20 mg dengan Kelompok Kontrol tidak terjadi penurunan suhu kurang dari 36 ${ }^{\circ} \mathrm{C}$ selama operasi, sedangkan pada kelompok kontrol terjadi penurunan suhu kurang dari 36 ${ }^{\circ} \mathrm{C}$ mulai menit ke-20 (Tabel 2).

Sejak sebelum induksi anestesia sampai dengan induksi akan dimulai terjadi penurunan tekanan darah sistol pada kedua kelompok, namun perbedaan tersebut tidaklah bermakna $(p>0,05)$. Pada saat 10 menit setelah induksi, tekanan sistol pada kedua kelompok mengalami kenaikan dan penurunan yang tidak signifikan. Hal ini terus berlangsung hingga menit ke-150. Pada saat menit ke-160, tekanan sistol kelompok nifedipin lebih tinggi daripada kelompok kontrol, namun tidak dapat diuji kebermaknaannya karena kelompok nifedipin 
Tabel 3 Perbandingan Rata-Rata dan Simpangan Baku Perkembangan Tekanan Sistol pada Kedua Kelompok

\begin{tabular}{|c|c|c|c|c|c|}
\hline \multirow{3}{*}{ Menit } & \multicolumn{4}{|c|}{ Nilai Rata-Rata dan Simpangan Baku Tekanan Sistol } & \multirow{3}{*}{ Nilai p } \\
\hline & \multicolumn{2}{|c|}{ Nifedipin $20 \mathrm{mg}$} & \multicolumn{2}{|c|}{ Kontrol } & \\
\hline & $(n=15)$ & SB & $(n=15)$ & SB & \\
\hline $\mathrm{T}_{\text {Sblm Induksi }}$ & 121,6 & 11,48 & 123,47 & 10,47 & 0,645 \\
\hline $\mathrm{T}_{0}$ & 111,33 & 14,16 & 116,4 & 10,01 & 0,267 \\
\hline $\mathrm{T}_{10}$ & 109,07 & 9,6 & 107,8 & 10,28 & 0,730 \\
\hline $\mathrm{T}_{20}$ & 114,8 & 6,97 & 112,67 & 11,31 & 0,539 \\
\hline $\mathrm{T}_{30}$ & 113,73 & 11,23 & 110,53 & 10,01 & 0,417 \\
\hline $\mathrm{T}_{40}$ & 111,4 & 8,25 & 115,53 & 8,49 & 0,187 \\
\hline $\mathrm{T}_{50}$ & 110,93 & 8,08 & 114,07 & 11,79 & 0,403 \\
\hline $\mathrm{T}_{60}$ & 112,13 & 7,95 & 112,73 & 11,91 & 0,872 \\
\hline $\mathrm{T}_{70}$ & 109,2 & 7,77 & 109,4 & 9,13 & 0,949 \\
\hline $\mathrm{T}_{80}$ & 111 & 9,91 & 112 & 10,62 & 0,792 \\
\hline $\mathrm{T}_{90}$ & 109,27 & 9,75 & 109,6 & 10,52 & 0,929 \\
\hline $\mathrm{T}_{100}$ & 110,8 & 9,62 & 113,6 & 9,23 & 0,423 \\
\hline $\mathrm{T}_{110}$ & 113,47 & 8,41 & 112,07 & 6,99 & 0,624 \\
\hline $\mathrm{T}_{120}$ & 113,64 & 9,44 & 112 & 10,08 & 0,666 \\
\hline $\mathrm{T}_{130}$ & 113,5 & 12,38 & 112 & 7,12 & 0,744 \\
\hline $\mathrm{T}_{140}$ & 115,14 & 7,76 & 115 & 5,54 & 0,969 \\
\hline $\mathrm{T}_{150}$ & 121,67 & 20,84 & 118,75 & 4,19 & 0,790 \\
\hline $\mathrm{T}_{160}$ & 135 & - & 104 & 9,9 & 0,237 \\
\hline $\mathrm{T}_{170}$ & - & & 120,5 & 19,09 & - \\
\hline
\end{tabular}

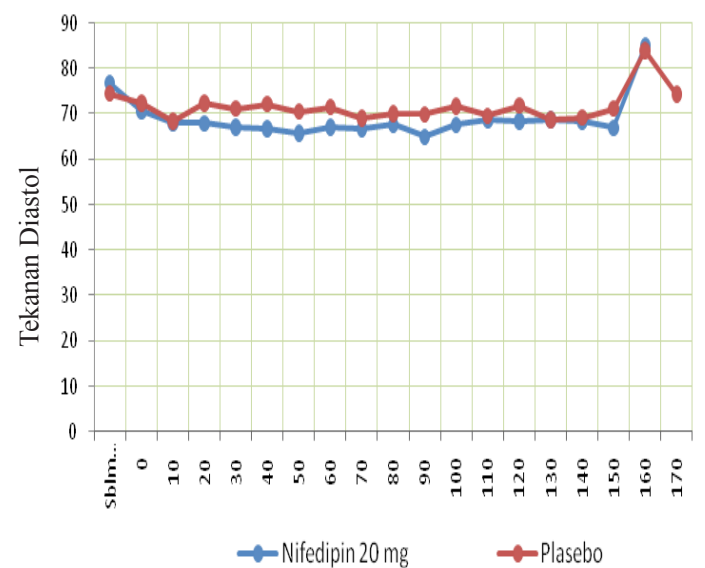

Gambar 3 Perbandingan Tekanan Diastol Rata-Rata Kelompok Nifedipin 20 mg dengan Kelompok Kontrol
$20 \mathrm{mg}$ hanya tersisa satu pasien yang masih dapat diamati.

Berdasarkan hasil pengukuran tersebut, maka dapat disimpulkan bahwa perkembangan tekanan darah sistol pada kelompok nifedipin $20 \mathrm{mg}$ dan kelompok kontrol saat sebelum dan juga setelah induksi tidak ada perbedaan bermakna ( $p>0,05$; Tabel 3, Gambar 2). Sejak sebelum sampai dengan akan dimulai induksi anestesia, kedua kelompok penelitian tersebut mengalami penurunan tekanan darah diastol, namun perbedaan tersebut tidaklah bermakna $(p>0,05)$. Perbedaan tekanan darah diastol kedua kelompok yang tidak berbeda bermakna 
Tabel 4 Perbandingan Rata-rata dan Simpangan Baku Perkembangan Tekanan Diastol pada Kedua Kelompok

\begin{tabular}{cccccc}
\hline & \multicolumn{2}{c}{ Nilai Rata-rata dan Simpangan Baku Perubahan Tekanan Diastol } & \\
\cline { 2 - 4 } & \multicolumn{2}{c}{ Nifedipin 20 $\mathbf{~ m g}$} & Kontrol & Nilai p \\
\cline { 2 - 5 } & $\mathbf{( n = 1 5 )}$ & $\mathbf{S B}$ & $\mathbf{( n = 1 5 )}$ & $\mathbf{S B}$ & \\
\hline $\mathrm{T}_{\text {sblm Induksi }}$ & 76,87 & 7,08 & 74,53 & 7,82 & 0,399 \\
$\mathrm{~T}_{0}$ & 70,67 & 8,97 & 72,4 & 8,89 & 0,599 \\
$\mathrm{~T}_{10}$ & 68 & 6,55 & 68,47 & 8,46 & 0,867 \\
$\mathrm{~T}_{20}$ & 68,07 & 6,71 & 72,4 & 9,73 & 0,167 \\
$\mathrm{~T}_{30}$ & 67,2 & 7,36 & 71,27 & 11,15 & 0,248 \\
$\mathrm{~T}_{40}$ & 66,87 & 6,3 & 72,27 & 9,22 & 0,071 \\
$\mathrm{~T}_{50}$ & 65,93 & 4,18 & 70,6 & 8,05 & 0,060 \\
$\mathrm{~T}_{60}$ & 67,27 & 4,64 & 71,6 & 7 & 0,055 \\
$\mathrm{~T}_{70}$ & 66,8 & 7,02 & 69,13 & 5,9 & 0,333 \\
$\mathrm{~T}_{80}$ & 67,73 & 9,37 & 70,2 & 9,72 & 0,485 \\
$\mathrm{~T}_{90}$ & 65,13 & 5,05 & 70 & 7,99 & 0,056 \\
$\mathrm{~T}_{100}$ & 67,73 & 7,32 & 71,87 & 9,49 & 0,192 \\
$\mathrm{~T}_{110}$ & 68,8 & 7,86 & 69,67 & 6,33 & 0,742 \\
$\mathrm{~T}_{120}$ & 68,43 & 6,36 & 71,92 & 7,38 & 0,198 \\
$\mathrm{~T}_{130}$ & 68,8 & 7,54 & 68,9 & 4,82 & 0,972 \\
$\mathrm{~T}_{140}$ & 68,43 & 6,55 & 69,29 & 4,75 & 0,784 \\
$\mathrm{~T}_{150}$ & 67 & 11,27 & 71,25 & 7,23 & 0,566 \\
$\mathrm{~T}_{160}$ & 85 & 0 & 84 & 7,07 & 0,927 \\
$\mathrm{~T}_{170}$ & - & & $74,5(2,12)$ & - \\
\hline & & & &
\end{tabular}

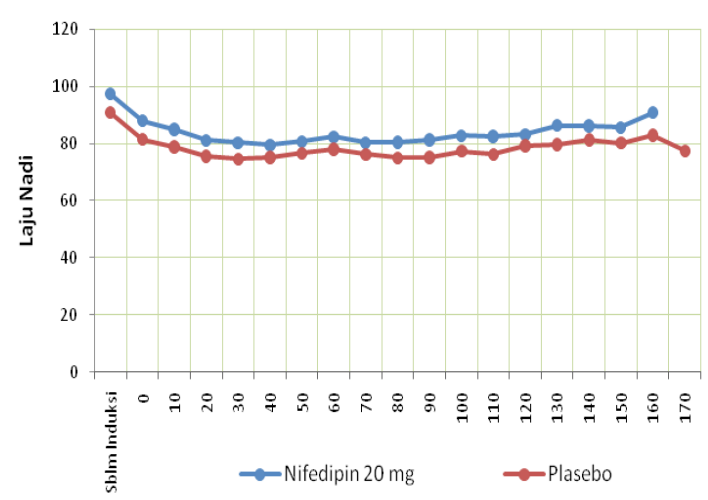

Gambar 4 Perbandingan Rata-rata Laju Nadi Kelompok Nifedipin 20 mg dengan Kelompok Kontrol
( $p>0,05)$ terus berlangsung hinga menit ke 160 setelah induksi. Dengan demikian, dapat disimpulkan bahwa perkembangan tekanan darah diastol pada kelompok nifedipin $20 \mathrm{mg}$ dan kelompok kontrol sebelum serta setelah induksi tidaklah berbeda bermakna ( $p>0,05$; Tabel 4, Gambar 3).

Sejak sebelum induksi hingga menit ke140, laju nadi kelompok nifedipin $20 \mathrm{mg}$ lebih tinggi daripada kelompok kontrol, akan tetapi perbedaan laju nadi kedua kelompok tersebut tidak berbeda secara bermakna, dari sebelum induksi, saat induksi hingga sampai menit ke 170 pascainduksi $(p>0,05)$, dengan demikian 
Tabel 5 Perbandingan Rata-rata dan Simpangan Baku Laju Nadi pada Kedua Kelompok

\begin{tabular}{|c|c|c|c|c|c|}
\hline \multirow{3}{*}{ Menit } & \multicolumn{4}{|c|}{ Nilai Rata-rata dan Simpangan Baku Perubahan Laju Nadi } & \multirow{3}{*}{ Nilai p } \\
\hline & \multicolumn{2}{|c|}{ Nifedipin $20 \mathrm{mg}$} & \multicolumn{2}{|c|}{ Kontrol } & \\
\hline & $(n=15)$ & SB & $(n=15)$ & SB & \\
\hline $\mathrm{T}_{\text {Sblm Induksi }}$ & 97,47 & 9,82 & 90,87 & 10,74 & 0,090 \\
\hline $\mathrm{T}_{0}$ & 88 & 9 & 81,47 & 13,3 & 0,126 \\
\hline $\mathrm{T}_{10}$ & 85 & 9,3 & 79 & 15,04 & 0,201 \\
\hline $\mathrm{T}_{20}$ & 81 & 7,7 & 75,67 & 10,03 & 0,113 \\
\hline $\mathrm{T}_{30}$ & 80,33 & 8,84 & 74,73 & 8,42 & 0,086 \\
\hline $\mathrm{T}_{40}$ & 79,53 & 8,29 & 75,33 & 7,32 & 0,152 \\
\hline $\mathrm{T}_{50}$ & 80,8 & 8,71 & 76,67 & 5,55 & 0,132 \\
\hline $\mathrm{T}_{60}$ & 82,33 & 6,75 & 78,13 & 4,93 & 0,062 \\
\hline $\mathrm{T}_{70}$ & 80,4 & 6,87 & 76,2 & 5,32 & 0,072 \\
\hline $\mathrm{T}_{80}$ & 80,53 & 8,69 & 75 & 7,58 & 0,074 \\
\hline $\mathrm{T}_{90}$ & 81,27 & 9,57 & 75,33 & 6,63 & 0,058 \\
\hline $\mathrm{T}_{100}$ & 82,8 & 10,14 & 77,4 & 7,65 & 0,111 \\
\hline $\mathrm{T}_{110}$ & 82,47 & 10,44 & 76,27 & 5,86 & 0,055 \\
\hline $\mathrm{T}_{120}$ & 83,21 & 8,73 & 79,31 & 5,94 & 0,189 \\
\hline $\mathrm{T}_{130}$ & 86,4 & 4,55 & 79,8 & 9,19 & 0,057 \\
\hline $\mathrm{T}_{140}$ & 86,29 & 5,31 & 81,29 & 13,39 & 0,386 \\
\hline $\mathrm{T}_{150}$ & 85,67 & 12,58 & 80,25 & 9,11 & 0,534 \\
\hline $\mathrm{T}_{160}$ & 91 & - & 83 & 4,24 & 0,367 \\
\hline $\mathrm{T}_{170}$ & - & & 77,5 & 16,26 & - \\
\hline
\end{tabular}

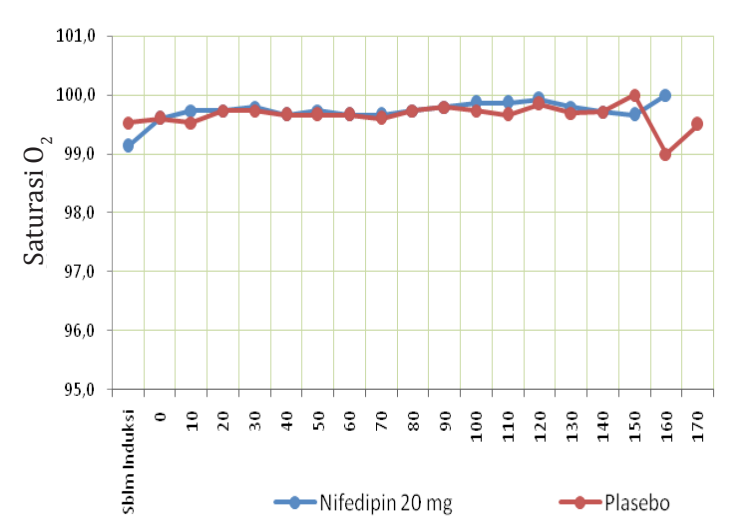

Gambar 5 Perbandingan Rata-rata Saturasi Oksigen Kelompok Nifedipin 20 mg dengan Kelompok Kontrol dapat ditarik simpulan bahwa perkembangan laju nadi pada kelompok nifedipin $20 \mathrm{mg}$ dan kelompok kontrol sebelum dan setelah induksi tidak ada perbedaan bermakna ( $p>0,05$; Tabel 5, Gambar 4). Sejak sebelum induksi hingga menit ke-150, saturasi oksigen pada kelompok nifedipin 20 mg dan kelompok kontrol tidak berbeda bermakna ( $p>0,05$; Tabel 6, Gambar $5)$.

\section{Pembahasan}

Penelitian telah dilakukan terhadap 30 pasien dengan status fisik ASA I-II, berusia 18 sampai 
Tabel 6 Perbandingan Rata-rata dan Simpangan Baku Saturasi Oksigen pada Kedua Kelompok

\begin{tabular}{|c|c|c|c|c|c|}
\hline \multirow{3}{*}{ Menit } & \multicolumn{4}{|c|}{ Nilai Rata-rata dan Simpangan Baku Perubahan Saturasi $\mathbf{0}_{2}$} & \multirow{3}{*}{ Nilai p } \\
\hline & \multicolumn{2}{|c|}{ Nifedipin $20 \mathrm{mg}$} & \multicolumn{2}{|c|}{ Kontrol } & \\
\hline & $(\mathrm{n}=15)$ & SB & $(n=15)$ & SB & \\
\hline $\mathrm{T}_{\text {Sblm Induksi }}$ & 99,13 & 0,99 & 99,53 & 0,52 & 0,176 \\
\hline $\mathrm{T}_{0}$ & 99,6 & 0,51 & 99,6 & 0,51 & 1,000 \\
\hline $\mathrm{T}_{10}$ & 99,73 & 0,46 & 99,53 & 0,64 & 0,333 \\
\hline $\mathrm{T}_{20}$ & 99,73 & 0,46 & 99,73 & 0,59 & 1,000 \\
\hline $\mathrm{T}_{30}$ & 99,8 & 0,41 & 99,73 & 0,46 & 0,679 \\
\hline $\mathrm{T}_{40}$ & 99,67 & 0,49 & 99,67 & 0,72 & 1,000 \\
\hline $\mathrm{T}_{50}$ & 99,73 & 0,46 & 99,67 & 0,72 & 0,765 \\
\hline $\mathrm{T}_{60}$ & 99,67 & 0,49 & 99,67 & 0,62 & 1,000 \\
\hline $\mathrm{T}_{70}$ & 99,67 & 0,49 & 99,6 & 0,63 & 0,749 \\
\hline $\mathrm{T}_{80}$ & 99,73 & 0,46 & 99,73 & 0,59 & 1,000 \\
\hline $\mathrm{T}_{90}$ & 99,8 & 0,41 & 99,8 & 0,56 & 1,000 \\
\hline $\mathrm{T}_{100}$ & 99,87 & 0,35 & 99,73 & 0,59 & 0,461 \\
\hline $\mathrm{T}_{110}$ & 99,87 & 0,35 & 99,67 & 0,49 & 0,209 \\
\hline $\mathrm{T}_{120}$ & 99,93 & 0,27 & 99,85 & 0,38 & 0,515 \\
\hline $\mathrm{T}_{130}$ & 99,8 & 0,42 & 99,7 & 0,48 & 0,628 \\
\hline $\mathrm{T}_{140}$ & 99,71 & 0,49 & 99,71 & 0,49 & 1,000 \\
\hline $\mathrm{T}_{150}$ & 99,67 & 0,58 & 100 & 0 & 0,423 \\
\hline $\mathrm{T}_{160}$ & 100 & - & 99 & 0 & - \\
\hline $\mathrm{T}_{170}$ & - & & 99,5 & 0,71 & - \\
\hline
\end{tabular}

60 tahun yang menjalani operasi modified radical mastectomy memakai anestesia umum. Penelitian dilakukan di kamar operasi dengan temperatur kamar operasi antara $23{ }^{\circ} \mathrm{C}$ sampai dengan $24{ }^{\circ} \mathrm{C}$. Lama puasa preoperasi semua subjek penelitian rata-rata 6 jam. Tidak ada subjek penelitian yang mendapatkan transfusi darah pada saat operasi sehingga cairan yang diberikan selama operasi hanya berdasarkan penggantian defisit cairan puasa. Jumlah cairan intravena total selama anestesi identik antara kedua kelompok. Tidak ditemukan komplikasi atau efek samping yang serius lainnya selama penelitian ini dilakukan. Penekanan masalah yang diteliti ialah derajat penurunan suhu inti tubuh selama anestesia umum pada kelompok prewarming nifedipin $20 \mathrm{mg}$ dibandingkan dengan kelompok kontrol. Prewarming yang dilakukan dalam penelitian ini adalah tindakan berupa pemberian nifedipin $20 \mathrm{mg}$ per oral 2 jam preoperasi.

Rancangan penelitian ini adalah penelitian kuantitatif intervensi dengan rancangan uji klinis acak terkontrol buta ganda yang telah dilakukan pada 30 pasien yang termasuk dalam kriteria inklusi. Data pasien yang ikut serta dalam penelitian ini dianalisis dan ditampilkan dalam hasil penelitian dan juga pembahasan. 
Tabel 1 mengenai perbandingan karakteristik antara kedua kelompok perlakuan yang tidak menunjukkan perbedaan bermakna, sehingga subjek penelitian telah homogen dan layak untuk diperbandingkan. Tidak terdapat subjek penelitian yang dikeluarkan selama penelitian ini berlangsung.

Teknik anestesia pada penelitian ini adalah anestesia umum, ketiga elemen termoregulasi meliputi input aferen, pemrosesan sinyal di pusat, dan respons eferen dapat dipengaruhi. Anestesia umum mengakibatkan pergeseran ambang respons vasokonstriksi, menggigil, vasodilatasi, dan berkeringat. Semua obat-obat anestesi umum memengaruhi termoregulasi dengan derajat yang hampir sama.

Saat satu jam pertama pascainduksi terjadi redistribusi panas tubuh dari inti tubuh ke perifer sehingga terjadi penurunan suhu inti tubuh 0,5 sampai $1,5^{\circ} \mathrm{C}$. Setelah itu penurunan suhu tubuh inti akan berlangsung lebih lambat, yang diakibatkan oleh proses kehilangan kalor yang melampaui daya produksinya oleh tubuh. Pada penelitian ini semua subjek penelitian mengalami penurunan suhu inti dalam 1 jam pertama. Penurunan suhu tubuh inti rata-rata pada kelompok nifedipin dalam 1 jam pertama adalah $0,97^{\circ} \mathrm{C}$, namun pada kelompok kontrol dalam 1 jam pertama adalah $1,71^{\circ} \mathrm{C}$. Penurunan suhu pada kelompok nifedipin berlangsung lebih lambat dibandingkan dengan kelompok kontrol. Pada pasien ini penurunan suhu pada 1 jam pertama anestesia selain oleh karena redistribusi panas dari pusat ke perifer juga oleh faktor pelepasan panas dari permukaan kulit ke lingkungan.

Penurunan suhu rata-rata pada kelompok kontrol $\left(0,10^{\circ} \mathrm{C}\right)$ lebih besar dibandingkan dengan kelompok nifedipin $20 \mathrm{mg}\left(0,07^{\circ} \mathrm{C}\right)$ dengan perbedaan yang bermakna $(p<0,05)$. Penurunan suhu pada kelompoknifedipin lebih minimal dibandingkan dengan kontrol. Hal ini terjadi karena tindakan prewarming berupa pemberian nifedipin $20 \mathrm{mg}$ melalui oral 2 jam sebelum operasi, akan meningkatkan kadar panas jaringan perifer, dengan demikian akan menurunkan redistribusi panas dari inti tubuh ke jaringan perifer setelah induksi anestesia. Proses redistribusi ini sangat bergantung pada besarnya gradien antara suhu inti dan perifer (permukaan kulit). Semakin sempit gradien antara suhu inti dan perifer, maka semakin kecil proses redistribusi.

Dari penelitian ini terlihat bahwa tindakan prewarming dengan pemberian nifedipin 20 mg 2 jam preoperasi bersifat memperlambat penurunan suhu. Selain itu, didapatkan juga bahwa pada kelompok nifedipin tidak terjadi hipotermia selama berlangsungnya operasi sehingga dapat dikatakan pemberian nifedipin $20 \mathrm{mg} 2$ jam preoperasi dapat juga mencegah hipotermia selama operasi.

Selain itu, proses kehilangan suhu dapat terjadi melalui beberapa mekanisme. Radiasi merupakan kontributor yang terbesar $(60 \%)$ dalam mekanisme perpindahan panas tubuh ke lingkungan. Sebanyak 20-27\% kehilangan kalor terjadi secara evaporasi. Mekanisme ini terjadi pada bagian tubuh manusia yang basah atau lembab yaitu mukosa, permukaan kulit yang lembab, serta paru-paru. Pada penelitian ini bagian tubuh pasien yang tidak ditutupi kain adalah wajah, tangan tempat pemasangan infus, probe saturasi, dan juga daerah operasi. Pada bagian tubuh yang tidak ditutupi, semua proses perpindahan panas tubuh yang meliputi radiasi, konveksi, konduksi, serta evaporasi dapat terjadi.

Konduksi merupakan proses transfer panas secara langsung antara dua materi padat yang berhubungan langsung tanpa disertai transfer panas molekul. Panas akan menjalar dari yang suhunya tinggi ke bagian yang memiliki suhu yang lebih rendah. Besarnya kalor yang hilang melalui proses tersebut akan bergantung pada faktor perbedaan suhu antara kulit dan benda padat yang menempel, dan juga konduktivitas dengan kulit mengakibatkan proses konduksi terutama apabila suhu benda tersebut berbeda jauh di bawah suhu permukaan kulit. Kain alas tempat tidur serta kain steril penutup pasien yang basah karena darah atau cairan irigasi dapat memperbesar derajat konduksi. Pada penelitian ini, proses pelepasan panas tubuh secara konduksi masih tetap terjadi.

Konveksi adalah suatu perambatan panas melalui aliran cairan atau gas. Besar konveksi bergantung pada luas kontak dan perbedaan 
suhu. Proses tersebut dipengaruhi oleh suhu permukaan kulit, suhu udara, luas permukaan kulit, dan kecepatan gerak udara di sekitar kulit. Kehilangan panas dengan cara ini kirakira mencapai 32\%. Pada penelitian ini hampir seluruh tubuh pasien tertutup dengan kain sehingga kehilangan panas melalui konveksi dapat diminimalisasi.

\section{Simpulan}

Berdasarkan padahasil penelitian, disimpulkan bahwa pemberian nifedipin $20 \mathrm{mg}$ per oral 2 jam preoperatif pada pasien yang menjalani operasi modified radical mastectomy dengan anestesia umum dapat mencegah hipotermia selama operasi dibandingkan dengan plasebo (kontrol).

\section{Daftar Pustaka}

1. Sessler DI. Temperature regulation and monitoring. Dalam: Miller RD, penyunting. Miller's anesthesia, Edisi ke-7. Philadelphia: Elsevier Churchill Livingston;. 2009. hlm. 1533-56.

2. Shawn F, Cagla E, Avery N, Darlene F, Anna G, Robin McL. Evidence-based guidelines for the prevention of perioperative hypothermia. For the best practice in general surgery (BPiGS) committee. Toronto: University of Toronto; 2008.
3. Marta P, Andrea C, Marco B, Giovanni P, Guido F. Clinical complication, monitoring and management of perioperative mild hypothermia: anesthesiological features. Acta Biomed. 2007;78:163-9.

4. Buggy DJ. Crossley WA. Thermoregulation, mild perioperative hypothermia and post anaesthetic shivering. BJA. 2000;84:61528.

5. Sessler DI. Complications and treatment of mild hypothermia. Anesthesiology. 2001; 95:531-43.

6. English MJM. Perioperative hypothermia: physical principles of heat transfer. Curr Anaesth Crit Care. 2001;12:66-71.

7. Kurz A. Perioperative hypothermia: effects of anaesthesia on thermoregulation. Curr Anaesth Crit Care. 2001;12:72-8.

8. Sessler DI. Mild perioperative hypothermia. N Engl J Med. 1997;336:24.

9. Pennsylvania Patient Safety Advisory. Prevention of inadvertent perioperative hypothermia. Patient Saf Advis. 2008 Jun;5(2):44-52

10. Butterworth JF, Mackey DC. Wasnick JD. Patient monitors. Dalam: Morgan GE, Mikhail MS, Murray MJ, penyunting. Clinical anesthesiology. New York: McGraw-Hill; 2006. hlm. 117-54.

11. Vassilieff N, Rosencher N, Conseiller C, Lienhart A. Nifedipine and intraoperative core body temperature in humans. Anesthesiology. 1994;80:123-8. 